\title{
A novel role for insulin resistance in the connection between obesity and postmenopausal breast cancer
}

\author{
MICHAEL WEICHHAUS ${ }^{1}$, JOHN BROOM $^{1}$, KLAUS WAHLE $^{2}$ and GIOVANNA BERMANO ${ }^{1}$ \\ ${ }^{1}$ Centre for Obesity Research and Epidemiology (CORE), Institute for Health and Welfare Research, \\ Robert Gordon University, Aberdeen; ${ }^{2}$ School of Medicine and Dentistry, College of Life Sciences \\ and Medicine, Medical School, University of Aberdeen, Aberdeen, UK
}

Received February 22, 2012; Accepted April 2, 2012

DOI: 10.3892/ijo.2012.1480

\begin{abstract}
The past two decades have seen a drastic increase in obesity rates in Western societies and emerging countries. As such, it has become increasingly important to understand the molecular mechanisms by which obesity affects the risk of developing associated co-morbidities. The present study aimed at identifying the effect of insulin on breast cancer and breast epithelial cells, reflective of obesity-associated hyperinsulinaemia, as a molecular explanation for the increased risk of oestrogen receptor-negative postmenopausal breast cancer in obese women. Both of the examined breast cancer cell lines (MDA-MB-231 and SK-BR-3) showed intact insulin signalling (insulin receptor phosphorylation and activation of phosphoinositol-3 kinase and mitogen-activated protein kinase cell signalling pathways), with MDA-MB-231 cells showing aberrantly amplified insulin signalling. Insulin did not induce a physiologically significant change in proliferation or apoptosis in either cell line. MDA-MB-231 cells showed decreased cell proliferation and increased S-phase population, while SK-BR-3 cells showed increased cyclin D and cyclin E gene expression and increased necrosis after insulin treatment. Hyperinsulinaemia may not be a universal mechanism by which obesity affects breast cancer progression. Normal breast epithelial cells (MCF-10A) showed intact insulin signalling, increased cell proliferation and reduced apoptosis after insulin treatment, suggesting cell growth and survival-promoting effects of insulin on these cells. Thus, hyperinsulinaemia may affect breast cancer aetiology rather than progression and this finding may provide a novel molecular mechanism for the role of insulin in
\end{abstract}

Correspondence to: Dr Giovanna Bermano, Centre for Obesity Research and Epidemiology (CORE), Institute for Health and Welfare Research, Robert Gordon University, Aberdeen AB25 1HG, UK E-mail: g.bermano@rgu.ac.uk

Abbreviations: IR, insulin receptor; ER, oestrogen receptor; AKT, protein kinase B; ERK, extracellular-regulated kinase; MAPK, mitogen-activated protein kinase; PI3-K, phosphoinositol-3 kinase

Key words: obesity, insulin resistance, breast cancer, cell proliferation, cell signalling, cell cycle, apoptosis the promotion of increased postmenopausal breast cancer risk in obese women.

\section{Introduction}

Latest statistics show that obesity affects more than $1 / 3$ of the adult population in the United States, with higher incidences in women $(1,2)$. With postmenopausal breast cancer incidence and mortality rates closely correlated with obesity (3), it is imperative to explore the underlying molecular mechanisms of this connection, as an increasing number of female patients will be in the obese postmenopausal group in the near future. Obesity is associated with concentration changes in the endocrine secretion profile of white adipose tissue. These changes, amongst others, contribute to the link between obesity and hyperinsulinaemia (4). Hyperinsulinaemia is consistently linked with increased breast cancer risk and mortality. An epidemiological study demonstrated a positive correlation between increased insulin resistance and increased risk of all cancers, even in nonobese individuals (5). A meta-analysis indicated an increased risk of development of and mortality from breast cancer in diabetic women (6). Another meta-analysis, examining C-peptide concentrations and breast cancer risk, showed a positive correlation in case/control studies (7). A large cohort study additionally observed a positive correlation between hyperinsulinaemia and breast cancer in their non-fasting postmenopausal sub-group (8). Additionally, fasting insulin concentrations at a young age were directly related to increased breast cancer incidences in later life (9). Similarly, in a case control study of Chilean women, insulin resistance was identified as a risk factor for developing breast cancer in postmenopausal women (10). Interestingly, in contrast to overall obesity, assessed by BMI, hyperinsulinaemia has also been linked to premenopausal breast cancer $(11,12)$, although this association was not consistently observed (13). Additionally, recent findings suggest that the combined effects of obesity and insulin resistance elevate certain biochemical markers generally associated with an increased risk of developing premenopausal breast cancer (14).

Previous studies have indicated that the main effect of obesity on breast cancer incidence rates is mediated by increasing oestrogen levels in obese postmenopausal women $(15,16)$. While the connection between obesity and oestrogen receptor (ER)-negative breast cancer incidence rates is lower than 
between obesity and ER-positive breast cancer, this association still indicates a connection between obesity and breast cancer, independent of oestrogen. Given the known interaction between the insulin receptor (IR) and oestrogen (17), this study used ER-negative cell lines.

In in vitro studies, high insulin concentrations increased cell growth in a number of cell lines $(18,19)$, including breast cancer cell lines $(20,21)$. The breast cancer cell line, MCF-7, is a wellestablished model of an ER-positive breast cancer. Stimulation with up to $100 \mathrm{nM}$ insulin has been shown to increase the ability of these cells to incorporate leucine and thymidine (20), increase fatty acid synthesis (22), increase cell cycle progression (23), protect against apoptosis (24), downregulate protein degradation and promote an increase in cell size (25). Treatment of MDA-MB-231 cells and other ER-negative breast cancer cell lines with up to $1 \mu \mathrm{M}$ insulin did not increase cell proliferation or affect apoptosis $(21,26)$. Conversely, MDA-MB-231 breast cancer cells have an elevated IR content as they carry an uncommon IR gene amplification (27), indicating that insulin may play a role in the metabolism of this cell line.

In this study, the influence of high insulin concentrations (100 nM) on several molecular aspects in breast cancer cells and breast epithelial cells was assessed. MDA-MB-231 and SK-BR-3 breast cancer cells were used to identify the impact of hyperinsulinaemia on oestrogen-independent breast cancer progression. MCF-10A cells were used representatively of normal breast epithelial cells to examine the impact of hyperinsulinaemia on breast cancer aetiology. Changes in insulin receptor phosphorylation, cell proliferation, activation of cell signalling pathways, changes in cell cycle and early apoptosis were determined.

\section{Materials and methods}

Materials. Human Caucasian breast adenocarcinoma cells, MDA-MB-231 (Cat no. 92020424, passage no. 36; European Collection of Cell Cultures, Salisbury, UK) and SK-BR-3 [American Type Culture Collection (ATCC) no. HTB-30, passage no. 28; ATCC, Manassas, VA, USA], were routinely cultured in RPMI-1640 medium (containing 25 mM HEPES, 1X glutamax) [Gibco (Invitrogen), Paisley, UK; Cat no. 72400], as recommended by the supplier and described previously (28). Human Caucasian breast epithelial cells, MCF-10A (ATCC no. CRL-10317, passage no. 102; ATCC), were cultured in DMEM/F-12 medium [Bio-Whittaker UK (Lonza Biologics), Slough, UK; Cat no. BE12-7199] as recommended by the supplier and described previously (28). The serum-free medium used was RPMI-1640 (25 mM HEPES, 1X glutamax) (Gibco) supplemented with $100 \mathrm{U} / \mathrm{ml}$ penicillin and $100 \mu \mathrm{g} / \mathrm{ml}$ streptomycin (Gibco) for MDA-MB 231 and SK-BR-3 cells and DMEM/F12 (Bio-Whittaker) supplemented with $100 \mathrm{U} / \mathrm{ml}$ penicillin and $100 \mu \mathrm{g} / \mathrm{ml}$ streptomycin for MCF-10A cells. Cell culture conditions were $37^{\circ} \mathrm{C}$ in humidified air containing $5 \% \mathrm{CO}_{2}$.

Cell proliferation assay. Cell proliferation was detected using a colorimetric Cell Proliferation ELISA kit (Roche Diagnostics, Penzberg, Germany; Cat no. 11647229 001), which assesses DNA replication by measuring bromodeoxyuridine (BrdU) incorporation. Cells $\left(5 \times 10^{3} /\right.$ well of each cell line) were plated in 96-well plates (Fisher Scientific; Cat no. 167008) with $100 \mu \mathrm{l} /$ well growth medium and incubated for $24 \mathrm{~h}$ at $37^{\circ} \mathrm{C}$. Cells were washed once in $100 \mu \mathrm{l} /$ well sterile PBS and incubated in serumfree medium for $24 \mathrm{~h}$. Cells were then washed as described above and treated for 24 or $48 \mathrm{~h}$ with $100 \mathrm{nM}$ insulin in $100 \mu \mathrm{l} /$ well serum-free medium. During treatment, the medium was supplemented with $10 \mu \mathrm{M}$ BrdU for the final $24 \mathrm{~h}$ of treatment. Incorporated BrdU was detected according to the manufacturer's instructions and colour development was quantified on a $\mu$ Quant Microplate Spectrophotometer (BioTek, Potton, UK) by measuring absorption at $450 \mathrm{~nm}$ with a reference wavelength of $690 \mathrm{~nm}$. Three experiments were performed for each cell line and each time-point. Each experiment consisted of six replicates for each treatment, i.e. six wells for the control and six wells for the treatment groups.

Insulin receptor phosphorylation assay. In $60-\mathrm{mm}^{2}$ tissue culture dishes (Fisher Scientific; Cat no. 150288), 1x10 ${ }^{6}$ cells of each of the three cell lines were plated and incubated in $3 \mathrm{ml}$ growth medium for $24 \mathrm{~h}$ at $37^{\circ} \mathrm{C}$. Cells were starved as described above and treated with $100 \mathrm{nM}$ insulin for $2 \mathrm{~min}$ at $37^{\circ} \mathrm{C}$. IR phosphorylation was determined using the DuoSet IC human phospho insulin receptor kit (R\&D Systems, Abingdon, UK; Cat no. DYC2718) following the manufacturer's instructions. In brief, cell lysate was prepared after treatment and added to a 96-well ELISA plate coated with $100 \mu \mathrm{l} /$ well of supplied capture antibody, targeting the IR $\beta$-subunit, at $8 \mu \mathrm{g} / \mathrm{ml}$. Detection was achieved by adding the supplied secondary antibody (100 $\mu \mathrm{l} /$ well), tagged with horseradish-peroxidase (HRP) and diluted 1:1,000, and by adding $100 \mu \mathrm{l}$ of a stable peroxide solution and tetramethylbenzidine solutions (R\&D Systems; Cat no. DY999), mixed 1:1, to each well. Absorption was quantified at $450 \mathrm{~nm}$ with a correction wavelength of $540 \mathrm{~nm}$ on a $\mu$ Quant microplate spectrophotometer (BioTek). Three experiments were performed for each cell line.

Phospho-kinase ELISA. Cell-based ELISA Phospho-AKT (S473) Immunoassay (Cat no. KCB887) and Phospho-ERK1/ ERK2 (T202/Y204) Immunoassay (Cat no. KCB1018) were purchased from R\&D Systems. Cells were grown and starved as before and treated as indicated in Fig. 3. The phosphorylation of protein kinase $\mathrm{B}$ (PKB/AKT) and extracellular-regulated kinase (ERK)1/2 was then assessed following the manufacturer's instructions. In brief, after fixing, the cells were incubated with phospho-AKT- or phospho-ERK1/2-specific mouse antibodies in conjunction with anti-total AKT- or anti-total ERK1/2specific rabbit antibodies, respectively. Phosphorylated and total protein was detected with species-specific secondary antibodies tagged with HRP and alkaline phosphatase (AP), respectively. Two different fluorescent substrates were used for quantification. Fluorescence was measured on a Fluoroskan Ascent microplate reader (Lab Systems, Hull, UK) with excitation at $544 \mathrm{~nm}$ and emission at $590 \mathrm{~nm}$ (phosphorylated protein) and excitation at $355 \mathrm{~nm}$ and emission at $460 \mathrm{~nm}$ (total protein). For each cell line three experiments were performed to assess AKT phosphorylation and three to assess ERK1/2 phosphorylation after insulin treatment. Each experiment included two replicates for each treatment time and the control.

\section{Flow cytometry}

Cell cycle. Changes in the cell distribution across cell cycle stages were assessed by measurement of DNA content in the 
A

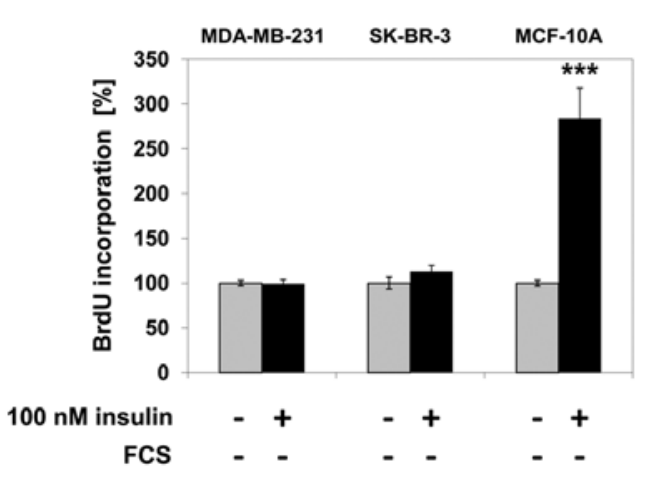

B

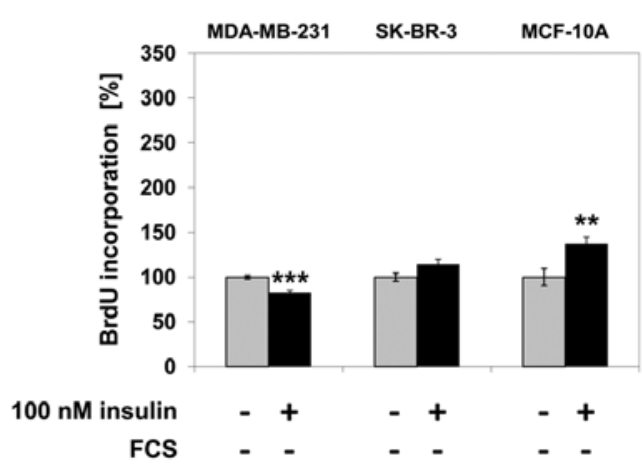

Figure 1. Changes in cell proliferation after treatment with $100 \mathrm{nM}$ insulin for (A) 24 or (B) $48 \mathrm{~h}$ in MDA-MB-231 and SK-BR-3 breast cancer cells and MCF-10A breast epithelial cells. Bars represent bromodeoxyuridine (BrdU) incorporation in relation to the respective control within each graph and expressed as a percentage thereof. Error bars represent \pm Standard Error of the Mean (SEM) of three experiments, each consisting of six replicates, i.e. 18 data points for each bar. ${ }^{* *}$ p $<0.01$, **** $\mathrm{p}<0.001$, denotes a significant difference compared to the control, obtained using one-way ANOVA analysis.

cells. The DNA specific dye used was propidium iodide (PI) (Sigma, Cat no. P4170). Cells were plated at $5 \times 10^{5}$ cells/well in six-well plates with $3 \mathrm{ml}$ growth medium and incubated for $24 \mathrm{~h}$ at $37^{\circ} \mathrm{C}$. Cells were starved for $24 \mathrm{~h}$ and then treated with $100 \mathrm{nM}$ insulin for $24 \mathrm{~h}$. Cells were harvested, stained and analysed as previously described (28). Three experiments were performed for each cell line, containing two replicates for the control and treatment groups.

Apoptosis. The Annexin V-FITC/7-AAD apoptosis kit (Beckman Coulter; Cat no. IM3614) was used to examine apoptosis following insulin treatment. The cells were grown (1x10\% dish) and treated with $100 \mathrm{nM}$ insulin in $60-\mathrm{mm}^{2}$ dishes as described above. After the cells had been treated and collected, $100 \mu \mathrm{l}$ of $1 \mathrm{X}$ binding buffer (supplied), $10 \mu \mathrm{l}$ Annexin V-FITC (supplied) and $20 \mu 1$ 7-AAD dye (supplied) were added to each tube. The samples were incubated on ice in the dark for $15 \mathrm{~min}$. The samples were then diluted 1:5 prior to analysis. Flow cytometry of the Annexin V-and 7-AAD-stained cells was performed using a Coulter Epics XLMCL flow cytometer (Beckman Coulter). Data were analysed using EXPO-32 Software (Applied Cytometry Systems, Sheffield, UK). Apoptotic cells were captured by linear FL-2 vs. area plots, with a cell line-specific upper cut-off point. Necrotic cells were similarly captured by linear FL-4 vs. area plots. Numbers were assessed after 10,000 events. Three experiments were performed for each cell lines with two replicates for the control and treatment groups.

$R T$-PCR. Cells were grown $\left(1 \times 10^{6} / \mathrm{dish}\right)$ and treated with $100 \mathrm{nM}$ insulin in $60-\mathrm{mm}^{2}$ dishes as described above. After the cells were treated, total-RNA was extracted using TRIzol (Invitrogen; Cat no. 15596). The extracted RNA (1 ng) was reverse-transcribed in a $20 \mu \mathrm{l}$ volume containing $50 \mathrm{mM}$ Tris- $\mathrm{HCl}$ (pH 8.3), $75 \mathrm{mM} \mathrm{KCl,} 3 \mathrm{mM} \mathrm{MgCl}, 10 \mathrm{mM}$ dithiothreitol (all from Invitrogen; Cat no. 18080-044), $1 \mathrm{mM}$ of each dNTP (Roche; Cat no. 11969064001), $100 \mu \mathrm{g} / \mathrm{ml} \mathrm{BSA} \mathrm{(New}$ England Biolabs; Cat no. B9001S), $25 \mu \mathrm{g} / \mathrm{ml}$ random primers (Promega; Cat no. C1181), 40 units RNaseOUT (Invitrogen; Cat no. 10777-019), 80 units SuperScript ${ }^{\circledR}$ III Reverse
Transcriptase (Invitrogen; Cat no. 18080-044) for $10 \mathrm{~min}$ at $25^{\circ} \mathrm{C}$, followed by $52 \mathrm{~min}$ at $42^{\circ} \mathrm{C}$ and $15 \mathrm{~min}$ at $72^{\circ} \mathrm{C}$. The resulting cDNA $(4 \mu \mathrm{l})$ was amplified with primers specific for cyclin D (forward primer, GCTCGAGCCCGTGAAAAAGA; reverse primer, CTCCGCCTCTGGCATTTTG) or cyclin E (forward primer, TTACCCAAACTCAACGTGCAA; reverse primer, GCTCAAAGTGCTGATCCC) and $\beta$-actin (forward primer, CATGTACGTTGCTATCCAGGC; reverse primer, CTCCTTAATGTCACGCACGAT) as the loading control, in a $20 \mu \mathrm{l}$ volume containing $10 \mathrm{mM}$ Tris- $\mathrm{HCl}$ ( $\mathrm{pH} 8.3), 50 \mathrm{mM} \mathrm{KCl}$, $1.75 \mathrm{mM} \mathrm{MgCl} 2,1$ unit of TaqDNA polymerase (all from Sigma; Cat no. D4545-250UN) and $1 \mu \mathrm{M}$ of each primer. Following a hot start $\left(95^{\circ} \mathrm{C}\right)$ and 4 min at $94^{\circ} \mathrm{C}, 25$ cycles for cyclin $\mathrm{D}$ and 33 cycles for cyclin $\mathrm{E}$ with $1 \mathrm{~min}$ at $94^{\circ} \mathrm{C}, 2 \mathrm{~min}$ at gene-specific annealing temperature $\left(60^{\circ} \mathrm{C}\right.$ for cyclin $\mathrm{D}, 59^{\circ} \mathrm{C}$ for cyclin $\mathrm{E}$ and $68^{\circ} \mathrm{C}$ for $\beta$-actin) and 2 min at $72^{\circ} \mathrm{C}$ were performed. This was followed by a 10 -min final extension step at $72^{\circ} \mathrm{C}$. PCR-products were separated on $1 \%$ agarose gels, images captured by GelDoc CCD imaging (Bio-Rad) and quantified by Quantity-One software (Bio-Rad).

\section{Results}

Effect of insulin on cell proliferation. In MDA-MB-231 cells, $100 \mathrm{nM}$ insulin treatment for $24 \mathrm{~h}$ did not increase cell proliferation; after $48 \mathrm{~h}$ of insulin treatment cell proliferation decreased by $18 \%(\mathrm{p}<0.001)$ compared to the untreated control. Cell proliferation did not change in SK-BR-3 cells after 24 or $48 \mathrm{~h}$ of treatment with $100 \mathrm{nM}$ insulin. In MCF-10A cells, proliferation increased by $184 \%(\mathrm{p}<0.001)$ after $24 \mathrm{~h}$ of insulin treatment and by $34 \%(\mathrm{p}<0.001)$ after $48 \mathrm{~h}$ of treatment compared to the untreated control (Fig. 1).

Effect of insulin treatment on IR phosphorylation. In MDA-MB-231 cells, IR phosphorylation increased by $380 \%$ ( $\mathrm{p}<0.001$ ) following 2 min of treatment with $100 \mathrm{nM}$ insulin compared to the untreated control. In SK-BR-3 cells, the increase in IR phosphorylation was $35 \%(\mathrm{p}<0.001)$ and $38 \%$ $(\mathrm{p}<0.001)$ in MCF-10A cells after 2 min of treatment compared to the untreated control (Fig. 2). 
2 min treatment

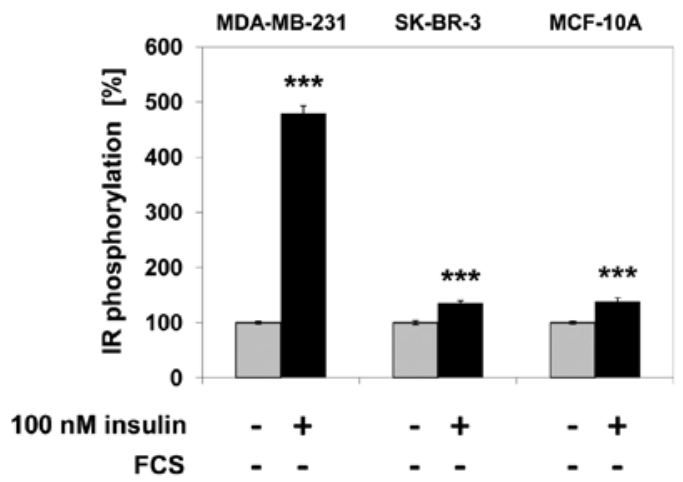

Figure 2. Changes in insulin receptor phosphorylation after treatment for $2 \mathrm{~min}$ with $100 \mathrm{nM}$ insulin in MDA-MB-231 and SK-BR-3 breast cancer cells and MCF-10A breast epithelial cells. Bars represent insulin receptor phosphorylation in relation to the control and expressed as a percentage thereof. Error bars represent \pm Standard Error of the Mean (SEM) of three experiments, each consisting of two replicates, i.e. six data points for each bar. ${ }^{* * *} \mathrm{p}<0.001$, significance value compared to the control, obtained using one-way ANOVA analysis.
Effect of insulin on cell signalling pathways. In MDA-MB-231 cells, AKT phosphorylation increased by $294 \%$ after $5 \mathrm{~min}$ ( $\mathrm{p}<0.001)$ and by $141 \%$ after $10 \mathrm{~min}(\mathrm{p}<0.001)$ of treatment with $100 \mathrm{nM}$ insulin compared to the untreated control. ERK1/2 phosphorylation did not change significantly after 5 or $10 \mathrm{~min}$ of insulin treatment. The phosphorylation of ERK1/2 increased by $95 \%$ after $15 \min (\mathrm{p}<0.001)$ and by $148 \%$ after $20 \mathrm{~min}$ $(\mathrm{p}<0.001)$ of treatment with $100 \mathrm{nM}$ insulin (Fig. 3A) compared to the untreated control. In SK-BR-3 cells, AKT phosphorylation increased by $67 \%$ after $5 \mathrm{~min}(\mathrm{p}<0.001)$ of treatment with $100 \mathrm{nM}$ insulin and no significant change in AKT-phosphorylation was observed after $10 \mathrm{~min}$ of treatment. The phosphorylation of ERK1/2 decreased by 15, 20 and 23\% after treatment with $100 \mathrm{nM}$ insulin for $5(\mathrm{p}=0.016), 10(\mathrm{p}=0.002)$ and $15 \mathrm{~min}$ $(\mathrm{p}<0.001)$, respectively, but did not significantly change after $20 \mathrm{~min}$ of insulin treatment compared to the untreated control (Fig. 3B). In MCF-10A cells, AKT phosphorylation increased by $75 \%$ after $5 \mathrm{~min}(\mathrm{p}=0.022)$ of treatment with $100 \mathrm{nM}$ insulin and no statistically significant change was observed after $10 \mathrm{~min}$ of
A

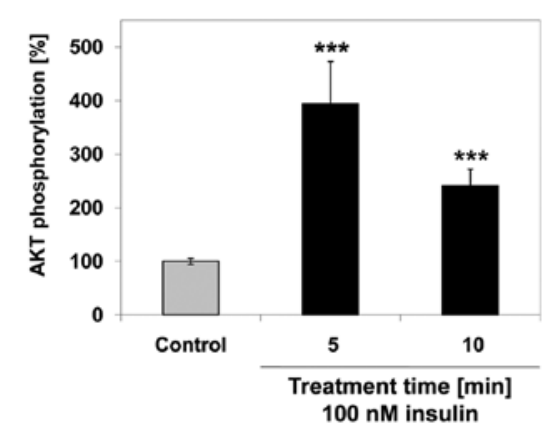

B

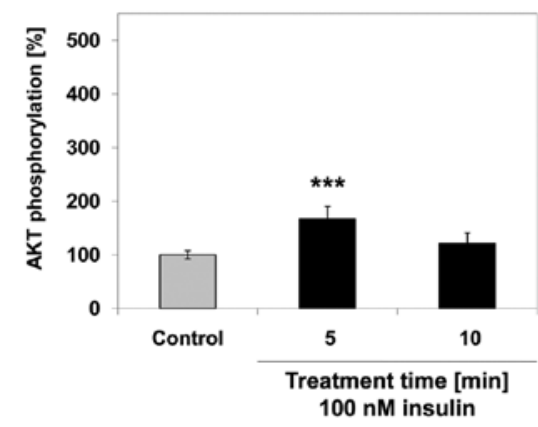

C

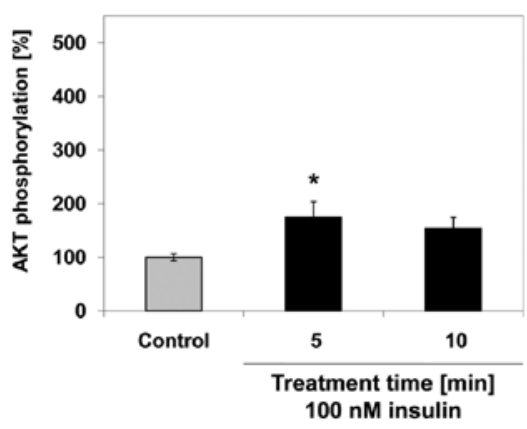

MDA-MB-231

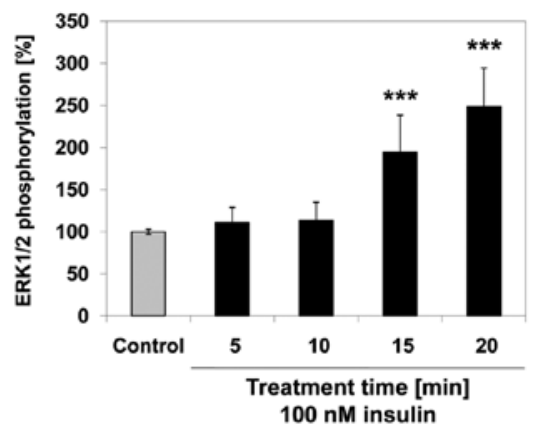

SK-BR-3

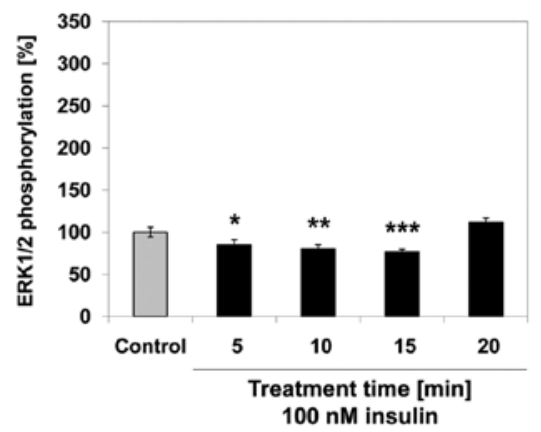

MCF-10A

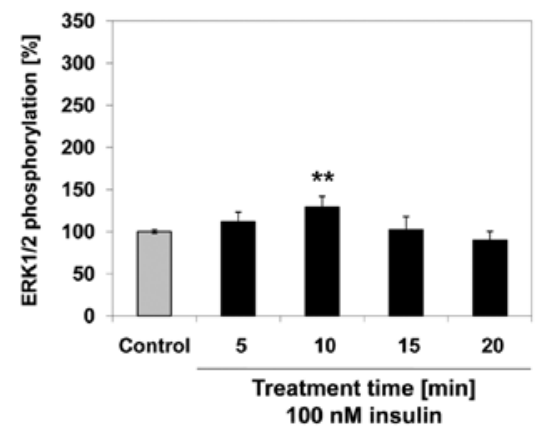

Figure 3. Changes in cell signalling pathway activation [PI3-K (left column graphs), MAPK (right column graphs)] after $100 \mathrm{nM}$ insulin treatment for 5-20 min in (A) MDA-MB-231 breast cancer cells, (B) SK-BR-3 breast cancer cells and (C) MCF-10A breast epithelial cells. Bars represent AKT phosphorylation or ERK1/2 phosphorylation in relation to the respective control within each graph and are expressed as a percentage thereof. Error bars represent \pm Standard Error of the Mean (SEM) of three experiments, each consisting of two replicates, i.e. six data points for each bar. ${ }^{*} \mathrm{p}<0.05,{ }^{* *} \mathrm{p}<0.01,{ }^{* * * *} \mathrm{p}<0.001$, denotes a significant difference compared to the control, obtained using Dunnett's post hoc t-test following univariate analysis of variance. 

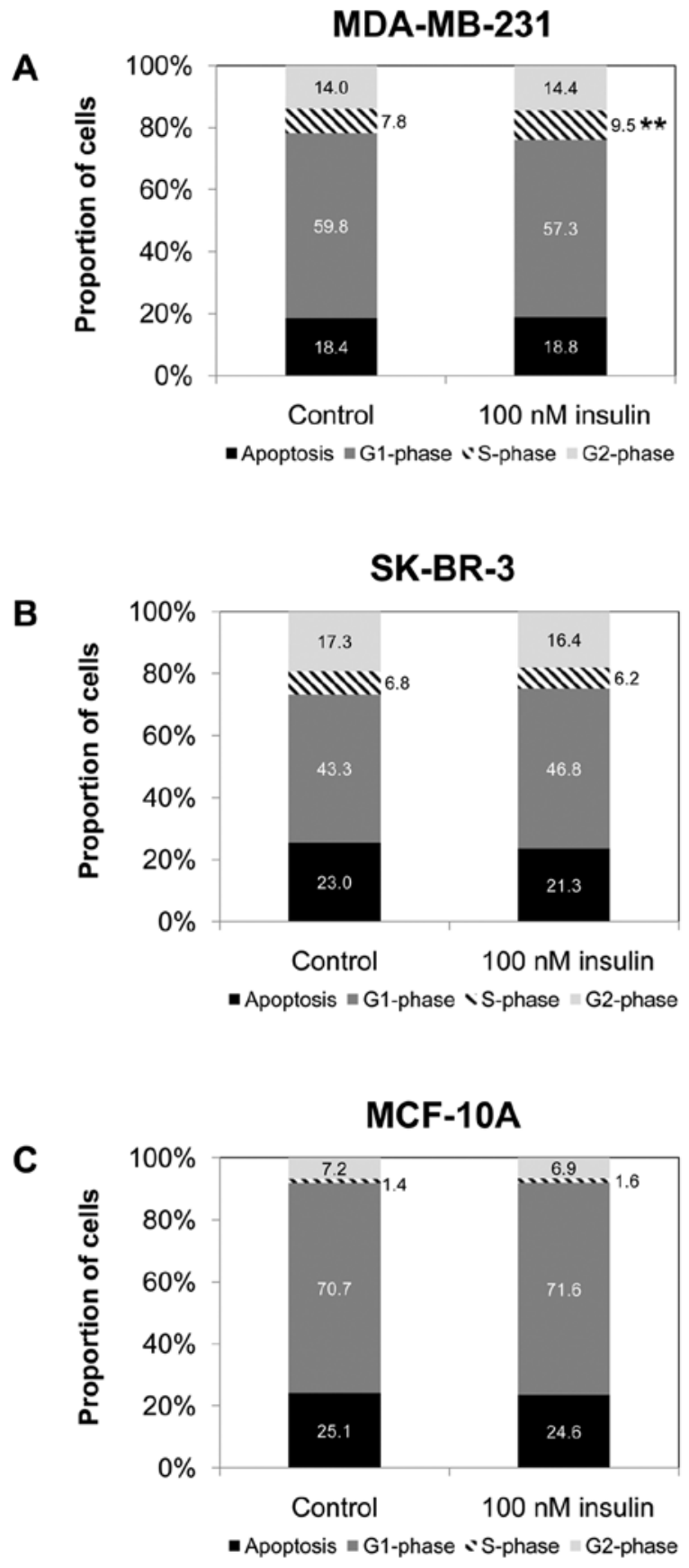

Figure 4. Changes in cell population distribution across the cell cycle stages after treatment for $24 \mathrm{~h}$ with $100 \mathrm{nM}$ insulin in (A) MDA-MB-231 breast cancer cells, (B) SK-BR-3 breast cancer cells and (C) MCF-10A breast epithelial cells. Bars represent the distribution of a cell population across cell cycle stages [including cells with a DNA content below that expected for the G1-phase (apoptosis)], obtained by examining 10,000 cells by flow cytometry. ${ }^{* * *} \mathrm{p}<0.01$ denotes a significant difference compared to the control of the same cell cycle stage, obtained using Dunnett's t-test following univariate analysis of variance.

insulin treatment. The phosphorylation of ERK1/2 increased by $29 \%$ after $10 \mathrm{~min}(\mathrm{p}=0.002)$ of treatment with $100 \mathrm{nM}$ insulin compared to the untreated control. No statistically significant change was observed at any other time-point (Fig. 3C).

Effect of insulin on cell cycle. In MDA-MB-231 cells, the S-phase population increased by 1.7 percentage points after $24 \mathrm{~h}(\mathrm{p}=0.002)$ of treatment with $100 \mathrm{nM}$ insulin compared to the S-phase popu- lation of the control cells (Fig. 4A). In SK-BR-3 and MCF-10A cells, treatment with $100 \mathrm{nM}$ insulin did not significantly change the distribution of the cell population across the cell cycle phase (Fig. 4B and C). In MDA-MB-231 and MCF-10A cells, cyclin D and cyclin $\mathrm{E}$ gene expression did not significantly change after up to $120 \mathrm{~min}$ of treatment with $100 \mathrm{nM}$ insulin compared to the untreated control (Fig. 5A and C). In SK-BR-3 breast cancer cells, cyclin D gene expression increased by $18 \%$ after $15 \mathrm{~min}$ $(\mathrm{p}=0.005)$ of treatment with $100 \mathrm{nM}$ insulin compared to the untreated control. Cyclin E gene expression increased by $22 \%$ after $15 \min (\mathrm{p}<0.001)$, by $19 \%$ after $30 \mathrm{~min}(\mathrm{p}=0.002)$, by $17 \%$ after $60 \mathrm{~min}(\mathrm{p}=0.003)$ and by $15 \%$ after $120 \mathrm{~min}(\mathrm{p}=0.012)$ of treatment with $100 \mathrm{nM}$ insulin compared with the untreated control (Fig. 5B).

Effect of insulin on apoptosis. In MDA-MB-231 breast cancer cells, treatment with $100 \mathrm{nM}$ insulin did not significantly change Annexin $\mathrm{V}$ detection or 7-AAD staining after $24 \mathrm{~h}$ of treatment (Fig. 6A). In SK-BR-3 breast cancer cells, Annexin V detection did not change significantly after $24 \mathrm{~h}$ of treatment with $100 \mathrm{nM}$ insulin. The percentage of cells with high levels of 7-AAD staining increased significantly by $9 \%$ after $24 \mathrm{~h}(\mathrm{p}=0.024)$ of $100 \mathrm{nM}$ insulin treatment (Fig. 6B). In MCF-10A breast epithelial cells, Annexin V detection decreased significantly by $13 \%$ after $24 \mathrm{~h}$ ( $\mathrm{p}=0.037$ ) of treatment with $100 \mathrm{nM}$ insulin compared to the untreated control. The amount of cells with high levels of 7-AAD staining did not change significantly after $24 \mathrm{~h}$ of treatment with $100 \mathrm{nM}$ insulin (Fig. 6C).

\section{Discussion}

The epidemiological link between obesity and breast cancer lacks a fundamental molecular mechanism explaining this connection. Insulin may be a molecular mediator of the obesity-breast cancer connection (29). Previous in vitro studies have indicated that insulin increases cell proliferation in ER-positive, but not in ER-negative breast cancer cells $(20,21,26,30)$. On the other hand, epidemiologically insulin and C-peptide levels have been linked to an increased risk of ER-negative breast cancer (31). This suggests an additional mode of action of insulin to increase breast cancer risk. Thus, in the present study, we investigated the effect of insulin on ER-negative cell lines to elucidate the impact of insulin independently of ER. Previously, when MDA-MB-231 breast cancer cells were treated with $100 \mathrm{nM}$ insulin, no increase in cell proliferation after $24 \mathrm{~h}$ was observed (21). Similarly, in the present study, we observed no increase in cell proliferation in this cell line after $24 \mathrm{~h}$ of treatment and a statistically significant decrease after $48 \mathrm{~h}$ of treatment, which may not be of physiological importance. In a previous study, it was concluded that the overexpression of glycoprotein PC-1 led to an inhibition of IR-autophosphorylation and consequently to a complete inhibition of insulin signalling in MDA-MB-231 breast cancer cells (32). Conversely, in the present study, we observed an increase in IR, AKT and ERK1/2 phosphorylation after insulin treatment, suggesting that insulin signalling in these cells is intact. Additionally a slight but statistically significant increase in the S-phase population was observed after insulin treatment, suggesting a potential effect of insulin on cell cycle progression. This observation however, was not supported by changes in cyclin D or cyclin $\mathrm{E}$ gene expression, indicating that the precise 
A

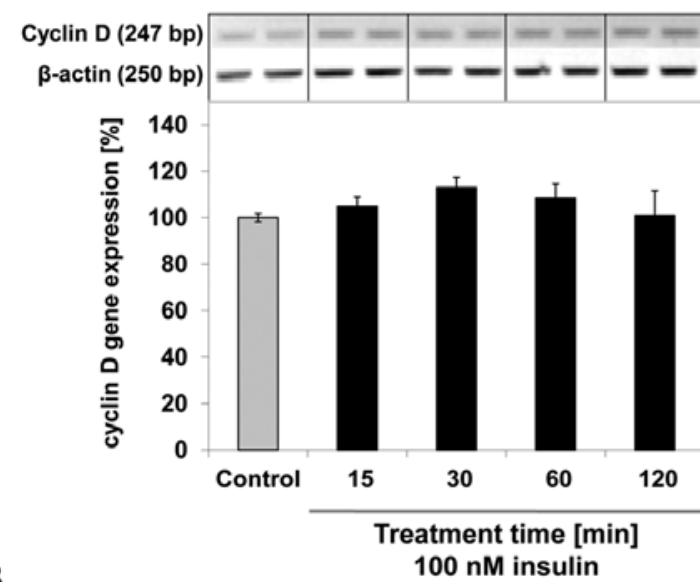

B

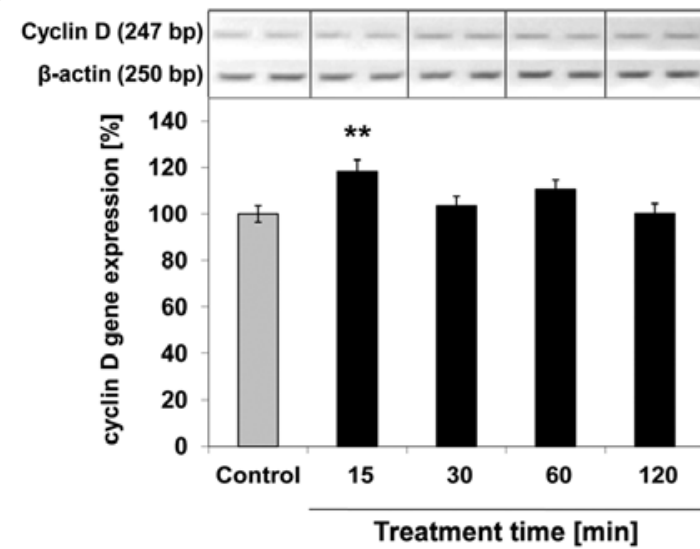

C

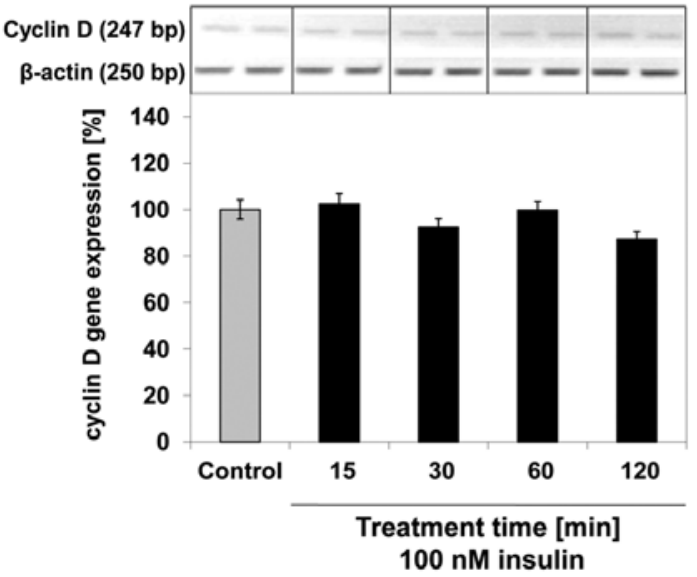

MDA-MB-231

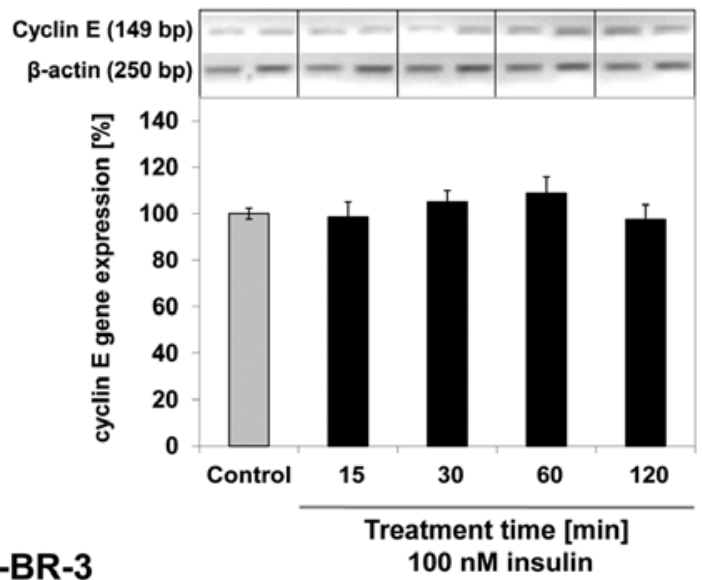

SK-BR-3
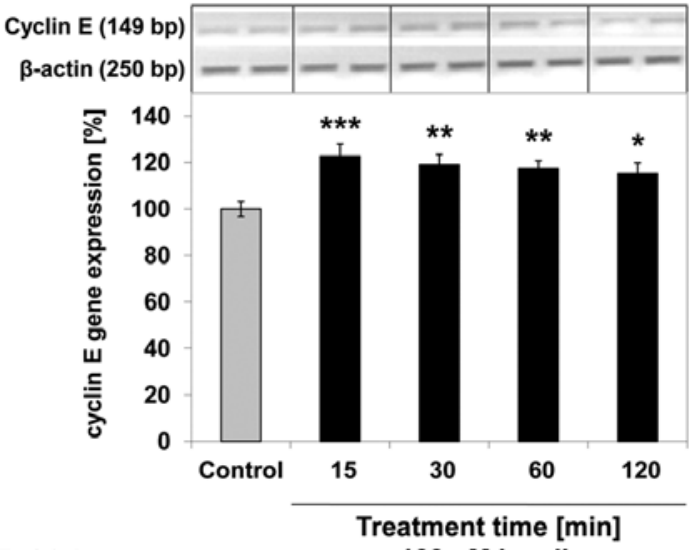

MCF-10A

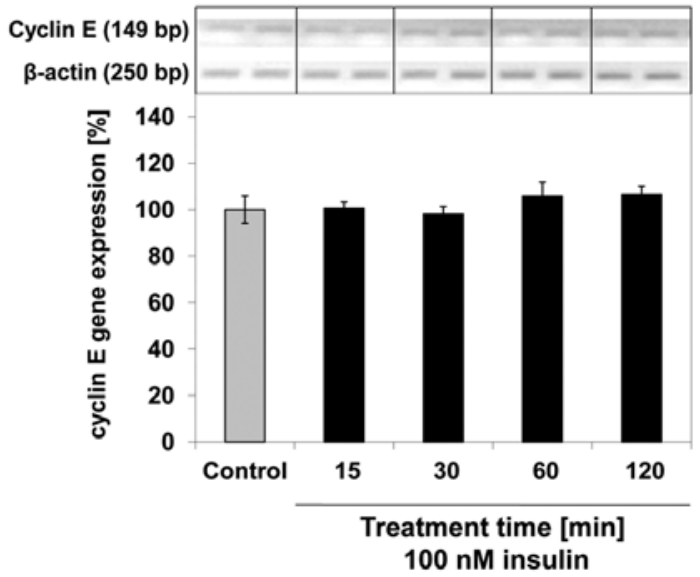

Figure 5. Changes in gene expression of cyclin D and cyclin E after $100 \mathrm{nM}$ insulin treatment for 15-120 min in (A) MDA-MB-231 breast cancer, (B) SK-BR-3 breast cancer and (C) MCF-10A breast epithelial cells. Gel images are representative of one of three repeated experiments. Bars represent percentage of cyclin D and cyclin E gene expression in relation to their respective control and expressed as a percentage thereof. Error bars represent \pm Standard Error of the Mean (SEM) of three experiments with two replicates, i.e. six data points for each bar. ${ }^{*} \mathrm{p}<0.05,{ }^{* *} \mathrm{p}<0.01,{ }^{* * *} \mathrm{p}<0.001$, denotes a significant difference compared to the control, obtained using Dunnett's post hoc t-test following univariate analysis of variance.

impact of insulin on the cell cycle in MDA-MB-231 breast cancer cells remains unclear. There was also no indication that insulin reduced apoptosis in these cells. A comparison to SK-BR-3 breast cancer cells and MCF-10A breast epithelial cells indicated that insulin signalling was amplified in these cells. However, this signal did not translate into significantly altered physiological changes. Thus, insulin may play a role in MDA-MB-231 cell metabolism, but not in increasing cell proliferation and in enhancing cell cycle progression or in decreasing apoptosis.
A second ER-negative breast cancer cell line, SK-BR-3, also showed no indications of increased cell proliferation after treatment with $100 \mathrm{nM}$ insulin for up to $48 \mathrm{~h}$. Further similarities to the MDA-MB-231 breast cancer cell line were the increase in IR and AKT phosphorylation. This increase, while statistically significant, did not reach the same level as in the MDA-MB-231 breast cancer cell line. This may be explained by the previously observed IR gene amplification in MDA-MB-231 breast cancer cells, which translated into the increased phosphorylation of 

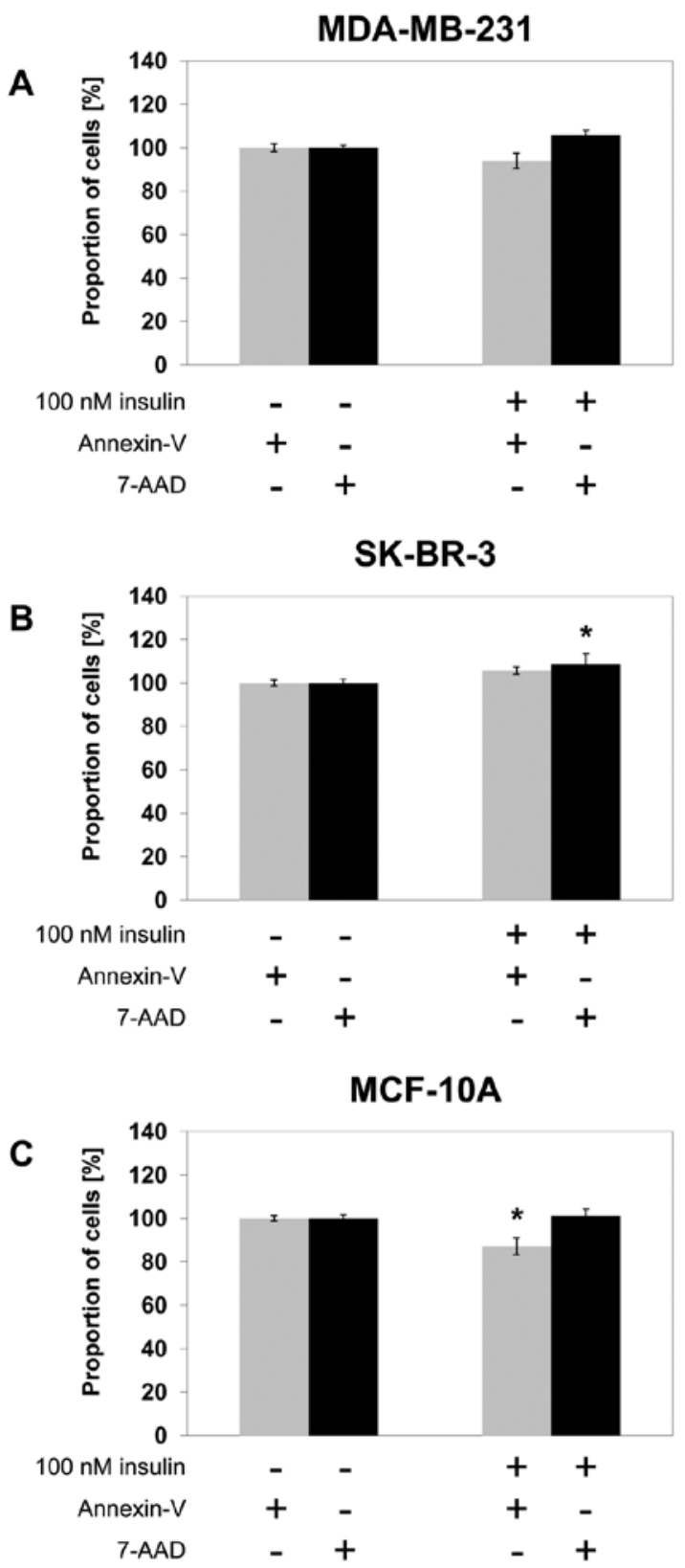

Figure 6. Changes in Annexin-V detection and 7-AAD staining after $100 \mathrm{nM}$ insulin treatment for $24 \mathrm{~h}$ in (A) MDA-MB-231 breast cancer cells, (B) SK-BR-3 breast cancer cells and (C) MCF-10A breast epithelial cells. Bars represent the percentage of cells above the lower cut-off point in the flow cytometry histogram in relation to the control and expressed as a percentage thereof. Error bars represent \pm Standard Error of the Mean (SEM) of three experiments with two replicates, i.e. six data points for each bar. ${ }^{*} \mathrm{p}<0.05$, denotes a significant difference compared to the control, obtained using Dunnett's post hoc t-test following univariate analysis of variance.

IR and IR targets, such as AKT and ERK1/2, when compared to the other cell lines (33). Additionally, MDA-MB-231 breast cancer cells have mutated Raf and Ras genes [members of the mitogen-activated protein kinase (MAPK) pathway], which may explain the difference in phosphorylation levels between the two breast cancer cell lines (34). Interestingly, ERK1/2 phosphorylation decreased with the insulin treatment of SK-BR-3 cells. This is in contrast to both MDA-MB-231 and MCF-10A cells, which showed increased ERK1/2 phosphorylation after insulin treatment, suggesting that this decrease is unique to the
SK-BR-3 cells. An explanation may be that insulin interferes with an underlying autocrine stimulus in these cells, which utilizes the MAP-kinase pathway but becomes inhibited as insulin signalling initiates changes in the same pathway. There was a significant increase in cyclin D and cyclin E gene expression after insulin treatment in SK-BR-3 breast cancer cells, indicating that insulin may increase cell cycle progression. As in MDA-MB-231 breast cancer cells, however, this observation was not supported by changes in cell population distribution across the cell cycle stages, which remained unaffected by insulin treatment of these cells. From these results, increased cell cycle progression cannot be predicted with a high degree of confidence in these cells. Furthermore, there was a small yet significant increase in necrosis with insulin treatment, which on its own would suggest cytotoxicity of insulin in these cells. Physiologically, these changes of increased cyclin expression and increased necrosis may be negligible, especially as they are seemingly contradictory and not supported by the additional analyses. Thus, similar to MDA-MB-231 breast cancer cells, high levels of insulin did not induce a uniform proliferative effect, even though insulin signalling seemed intact.

The most interesting question arising from the results presented in this study is what the physiological effect of insulin on ER-negative breast cancer cells is, given that insulin signalling is intact and for MDA-MB-231 breast cancer cells even amplified. While our results did not validate a previous explanation for insulin resistance in MDA-MB-231 breast cancer cells, it is still likely that ER-negative breast cancer cells may have acquired insulin resistance. If the condition of ER negativity in cells was regarded as an enhancer of breast cancer progression and not an $a b$ initio determinant, it could be speculated that acquired insulin resistance may be an additional feature of breast cancer progression. This would explain the connection of induced cell proliferation in ER-positive but not in ER-negative cells.

MCF-10A breast epithelial cells were also analysed following insulin treatment. Similar to the breast cancer cell lines, normal insulin signalling, IR phosphorylation and AKT and ERK1/2 phosphorylation, were intact. The increase in the phosphorylation of these pathways was similar to that observed for the SK-BR-3 but not the MDA-MB-231 breast cancer cell line, further emphasizing the highly aberrant insulin signalling in MDA-MB-231 breast cancer cells. In contrast to the effects in both breast cancer cell lines, however, insulin treatment induced cell proliferation in MCF-10A cells and a significant decrease in apoptosis. These results suggest a significant physiological impact of insulin on cell growth and reduction of apoptosis in these non-malignant epithelial cells. Clearly, there is sufficient evidence to suggest a significant growth-promoting and survivalinducing effect of insulin on MCF-10A breast epithelial cells. This is a novel finding and may suggest that insulin could play a role in the aetiology of postmenopausal breast cancer attributable to obesity.

Epithelial cells rather than breast cancer cells may be more susceptible to insulin-induced proliferative pressure. Thus, insulin may have a greater impact on breast cancer aetiology than on breast cancer progression (at least for progression of ER-negative breast cancers). This may provide a novel molecular explanation for the frequently proposed, but unsatisfactorily explained role of insulin in the promotion of increased postmenopausal breast cancer risk in obese women. 


\section{Acknowledgements}

This study was supported by a Robert Gordon University Research and Development Initiative postgraduate research student fellowship, NHS Endowment Trust and Breast Cancer Campaign.

\section{References}

1. Flegal KM, Carroll MD, Kuczmarski RJ and Johnson CL: Overweight and obesity in the United States: prevalence and trends, 1960-1994. Int J Obes Relat Metab Disord 22: 39-47, 1998

2. Flegal KM, Carroll MD, Ogden CL and Curtin LR: Prevalence and trends in obesity among US adults, 1999-2008. JAMA 303 235-241, 2010.

3. Calle EE, Rodriguez C, Walker-Thurmond $\mathrm{K}$ and Thun MJ: Overweight, obesity, and mortality from cancer in a prospectively studied cohort of U.S. adults. N Engl J Med 348 1625-1638, 2003.

4. Antuna-Puente B, Feve B, Fellahi S and Bastard JP: Adipokines: the missing link between insulin resistance and obesity. Diabetes Metab 34: 2-11, 2008.

5. Facchini FS, Hua N, Abbasi F and Reaven GM: Insulin resistance as a predictor of age-related diseases. J Clin Endocrino Metab 86: 3574-3578, 2001.

6. Larsson SC, Mantzoros CS and Wolk A: Diabetes mellitus and risk of breast cancer: a meta-analysis. Int J Cancer 121: 856-862, 2007.

7. Pisani P: Hyper-insulinaemia and cancer, meta-analyses of epidemiological studies. Arch Physiol Biochem 114: 63-70, 2008

8. Verheus M,Peeters PH, Rinaldi S, Dossus L, Biessy C, Olsen A, Tjonneland A, Overvad K, Jeppesen M, Clavel-Chapelon F, Tehard B, Nagel G, Linseisen J, Boeing H, Lahmann PH, Arvaniti A, Psaltopoulou T, Trichopoulou A, Palli D, Tumino R, Panico S, Sacerdote C, Sieri S, van Gils CH, Buenode-Mesquita BH, Gonzalez CA, Ardanaz E, Larranaga N, Garcia CM, Navarro C, Quiros JR, Key T, Allen N, Bingham S, Khaw KT, Slimani N, Riboli E and Kaaks R: Serum C-peptide levels and breast cancer risk: results from the European Prospective Investigation into Cancer and Nutrition (EPIC). Int J Cancer 119: 659-667, 2006.

9. Gunter MJ, Hoover DR, Yu H, Wassertheil-Smoller S, Rohan TE, Manson JE, Li J, Ho GY, Xue X, Anderson GL, Kaplan RC, Harris TG, Howard BV, Wylie-Rosett J, Burk RD and Strickler HD: Insulin, insulin-like growth factor-I, and risk of breast cancer in postmenopausal women. J Natl Cancer Inst 101: 48-60, 2009.

10. Garmendia ML, Pereira A, Alvarado ME and Atalah E: Relation between insulin resistance and breast cancer among Chilean women. Ann Epidemiol 17: 403-409, 2007.

11. Del Giudice ME, Fantus IG, Ezzat S, McKeown-Eyssen G, Page D and Goodwin PJ: Insulin and related factors in premenopausal breast cancer risk. Breast Cancer Res Treat 47: 111-120, 1998.

12. Goodwin PJ, Ennis M, Pritchard KI, Trudeau ME, Koo J, Madarnas Y, Hartwick W, Hoffman B and Hood N: Fasting insulin and outcome in early-stage breast cancer: results of a prospective cohort study. J Clin Oncol 20: 42-51, 2002.

13. Eliassen AH, Tworoger SS, Mantzoros CS, Pollak MN and Hankinson SE: Circulating insulin and c-peptide levels and risk of breast cancer among predominately premenopausal women. Cancer Epidemiol Biomarkers Prev 16: 161-164, 2007.

14. Alokail MS, Al-Daghri NM, Al-Attas OS and Hussain T: Combined effects of obesity and type 2 diabetes contribute to increased breast cancer risk in premenopausal women. Cardiovasc Diabetol 8: 33, 2009.
15. Purohit A, Newman SP and Reed MJ: The role of cytokines in regulating estrogen synthesis: implications for the etiology of breast cancer. Breast Cancer Res 4: 65-69, 2002.

16. Stephenson GD and Rose DP: Breast cancer and obesity: an update. Nutr Cancer 45: 1-16, 2003.

17. Lanzino M, Morelli C, Garofalo C, Panno ML, Mauro L, Ando $\mathrm{S}$ and Sisci D: Interaction between estrogen receptor alpha and insulin/IGF signaling in breast cancer. Curr Cancer Drug Targets 8: 597-610, 2008.

18. Straus DS: Growth-stimulatory actions of insulin in vitro and in vivo. Endocr Rev 5: 356-369, 1984.

19. Whittaker J, Okamoto AK, Thys R, Bell GI, Steiner DF and Hofmann CA: High-level expression of human insulin receptor cDNA in mouse NIH 3T3 cells. Proc Natl Acad Sci USA 84: 5237-5241, 1987.

20. Osborne CK, Bolan G, Monaco ME and Lippman ME: Hormone responsive human breast cancer in long-term tissue culture: effect of insulin. Proc Natl Acad Sci USA 73: 4536-4540, 1976.

21. Costantino A, Milazzo G, Giorgino F, Russo P, Goldfine ID, Vigneri R and Belfiore A: Insulin-resistant MDA-MB231 human breast cancer cells contain a tyrosine kinase inhibiting activity. Mol Endocrinol 7: 1667-1676, 1993.

22. Monaco ME and Lippman ME: Insulin stimulation of fatty acid synthesis in human breast cancer in long term tissue culture. Endocrinology 101: 1238-1246, 1977.

23. Gross GE, Boldt DH and Osborne CK: Perturbation by insulin of human breast cancer cell cycle kinetics. Cancer Res 44: 3570-3575, 1984

24. Geier A, Beery R, Haimshon M, Hemi R and Lunenfeld B: Serum and insulin inhibit cell death induced by cycloheximide in the human breast cancer cell line MCF-7. In Vitro Cell Dev Biol 28A: 415-418, 1992.

25. Faridi J, Fawcett J, Wang L and Roth RA: Akt promotes increased mammalian cell size by stimulating protein synthesis and inhibiting protein degradation. Am J Physiol Endocrinol Metab 285: E964-E972, 2003.

26. Godden J, Leake R and Kerr DJ: The response of breast cancer cells to steroid and peptide growth factors. Anticancer Res 12: 1683-1688, 1992

27. Papa V, Milazzo G, Goldfine ID, Waldman FM and Vigneri R: Sporadic amplification of the insulin receptor gene in human breast cancer. J Endocrinol Invest 20: 531-536, 1997.

28. Weichhaus M, Broom I and Bermano G: The molecular contribution of TNF- $\alpha$ in the link between obesity and breast cancer. Oncol Rep 25: 477-483, 2011.

29. Lorincz AM and Sukumar S: Molecular links between obesity and breast cancer. Endocr Relat Cancer 13: 279-292, 2006.

30. Osborne CK, Monaco ME, Lippman ME and Kahn CR: Correlation among insulin binding, degradation, and biological activity in human breast cancer cells in long-term tissue culture. Cancer Res 38: 94-102, 1978.

31. Hirose K, Toyama T, Iwata H, Takezaki T, Hamajima N and Tajima K: Insulin, insulin-like growth factor-I and breast cancer risk in Japanese women. Asian Pac J Cancer Prev 4: 239-246, 2003.

32. Belfiore A, Costantino A, Frasca F, Pandini G, Mineo R, Vigneri P,Maddux B, Goldfine ID and VigneriR: Overexpression of membrane glycoprotein PC-1 in MDA-MB231 breast cancer cells is associated with inhibition of insulin receptor tyrosine kinase activity. Mol Endocrinol 10: 1318-1326, 1996.

33. Papa V, Pezzino V, Costantino A, Belfiore A, Giuffrida D, Frittitta L, Vannelli GB, Brand R, Goldfine ID and Vigneri R: Elevated insulin receptor content in human breast cancer. J Clin Invest 86: 1503-1510, 1990

34. Hollestelle A, Elstrodt F, Nagel JH, Kallemeijn WW and Schutte M: Phosphatidylinositol-3-OH kinase or RAS pathway mutations in human breast cancer cell lines. Mol Cancer Res 5: 195-201, 2007. 